\title{
HeTEROgENEIDADE E TENDÊNCIAS ATUAIS Do SindiCALISMO DE Classe MÉdia No BRASIL
}

\section{Márcia Maria Corsi Moreira Fantinatti}

RESUMO: Este artigo pretende analisar particularidades do sindicalismo de classe média que o diferenciam do sindicalismo operário. Apresenta, também, alguns elementos para uma análise comparativa entre diversos setores que compõem a classe média, à qual não consideramos como um bloco homogêneo: haveria setores que aderiram ao sindicalismo e os que não o fizeram. Os estudos citados referem-se a: professores, advogados, engenheiros, arquitetos, professores universitários, médicos, comerciários, gerentes, bancários e funcionários públicos. Por último, indica algumas transformações recentes que vêm afetando a classe média e que poderão trazer conseqüências para seus respectivos sindicatos.

UNITERMOs: Sindicalismo; Classes Sociais; Classe Média.

\section{INTRODUÇÃo}

No presente artigo procuramos enfocar o comportamento dos assalariados de classe média frente ao sindicalismo. Com isso, pretendemos agregar novas reflexões teóricas ao debate sobre a heterogeneidade das classes trabalhadoras e sobre os movimentos sindicais de assalariados médios. ${ }^{1}$

${ }^{1} \mathrm{O}$ tema tratado no presente artigo vem sendo desenvolvido em nosso trabalho de pesquisa de Doutorado. Constitui uma ampliação do tema de nossa dissertação de mestrado, na qual 
Problematizamos a resistência de alguns setores da classe média brasileira em aderir à organização e à luta sindical, e apontamos elementos para a análise dos movimentos sindicais dos assalariados médios que aderiram a esse movimento. Trata-se de um estudo inicial, inserido num objetivo mais amplo que é o de apreender a particularidade das reivindicações, das formas de organização e dos métodos de ação sindical de diferentes setores dos assalariados médios.

Partimos da hipótese que o comportamento da classe média frente ao sindicalismo é distinto do comportamento dos trabalhadores pertencentes à classe operária. Também presumimos que é possível explicitar uma heterogeneidade no interior da classe média, ou seja, que os grupos que a compõem possuem especificidades que não permitem toma-la como bloco homogêneo.

Tomamos em consideração estudos realizados sobre os seguintes setores da classe média: professores universitários, professores de $1^{\circ}$ e $2^{\circ}$ graus, comerciários, bancários, médicos, engenheiros, arquitetos, advogados, gerentes e funcionários públicos e iniciamos uma análise comparativa.

Propomo-nos ainda a indicar algumas tendências atuais dos sindicalismos de classe média, considerando transformações nas relações de trabalho que atingem esse setor social. Com vistas ao levantamento de tais tendências, destacamos alguns dos impactos da conjuntura políticoeconômica recente, com destaque para as modificações na legislação que rege o funcionamento da Previdência Social, bem como leis específicas na área de serviços públicos que preconizam a diminuição do mesmo e ampliação do setor privado.

Ressaltamos a importância da análise das modificações em curso, dadas as possibilidades de identificar novas tendências no movimento sindical, no que se refere aos setores dos assalariados médios de maneira particular.

\footnotetext{
fizemos um estudo de caso do sindicalismo dos professores universitários. Márcia M. C. M. Fantinatti. Sindicalismo de Classe Média e Meritocracia: o movimento docente na Universidade Pública. Campinas, 1998. Dissertação (Mestrado em Sociologia) - IFCH/Unicamp.
} 


\section{Classe Média, Classe Operária e Pequena Burguesia}

A análise das tendências atuais do sindicalismo de classe média pressupõe um debate bibliográfico sobre as definições das classes sociais no capitalismo atual.

Dentre as principais correntes teóricas que buscam uma definição para as classes sociais, destacam-se, principalmente, duas tradições. Uma delas, referindo-se ao conjunto dos trabalhadores assalariados como um bloco homogêneo, atribuiu-lhes, genericamente, a denominação classe trabalhadora. Diversos autores posicionam-se nessa perspectiva, que engloba sobretudo os de tradição comunista. Em comum, utilizam um conceito amplo para definir a classe operária, em que identificam-na ao conjunto dos assalariados. Segundo indicam, pertenceriam ao proletariado os não-proprietários dos meios de produção (Rumiantsev et al., 1963). Tais autores contrapõem-se à idéia de que uma nova classe média estaria expandindo-se; entendem que o que haveria é um proletariado dividido em frações: uma composta pelos operários industriais (o núcleo da classe operária); outra, pelo proletariado "de escritório", que comporia uma franja periférica da classe operária. Ao analisarem a estrutura de classes sob o capitalismo, descartam especificidades como qualificação profissional, nível salarial, situação de trabalho, ideologia, pois, segundo argumentam, não introduziriam diferenças de classe. A divisão capitalista do trabalho é apresentada como se constituísse em mero dado técnico, visão que pode ser ilustrada sobretudo ao afirmarem que toda sociedade necessitaria de engenheiros. Para explicar porque inúmeros trabalhadores mantém-se distantes do movimento sindical e dos partidos operários, limitam-se a referi-los utilizando a expressão "consciência deslocada". De todo modo, concluem que os assalariados tendem à "proletarização universal", recusando a idéia da heterogeneidade das classes trabalhadoras e da existência de uma "classe média". 
A essa forma de interpretação da estrutura de classes, que pode ser denominada genericamente de "tese da proletarização" podem ser agregadas as idéias desenvolvidas por Braverman (1981). Esse autor, embora também utilize um conceito amplo de proletariado não baseia sua argumentação apenas no assalariamento para negar a importância da heterogeneidade das classes trabalhadoras. Segundo argumenta, as novas tecnologias empregadas na produção, bem como os novos métodos de organização do trabalho - seguindo modelos de gerência científica - utilizados pelos capitalistas para manter a taxa de acumulação, levariam ao crescimento do exército de reserva e, com isso, à deterioração das condições de venda da força de trabalho. $\mathrm{O}$ aumento de trabalhadores em atividades realizadas em escritórios, teria sido acompanhado por crescente padronização e rotinização do trabalho. Ou seja, houve a burocratização das tarefas, tornando-as processos cada vez mais repetitivos e rotineiros, apoiados em mecanização e operações não qualificadas. Isso aproximaria a realidade vivida pelos trabalhadores de escritório à dos operários das fábricas. O trabalho tenderia, enfim, a caracterizar-se pela homogeneização.

Foi fora dos referenciais teóricos marxistas que surgiram estudos que enfatizam a existência de diferenciações significativas no interior do conjunto de assalariados sob o capitalismo monopolista, trabalhando com conceitos que operam com, ao menos, uma divisão: classe operária e classe média. Teóricos ligados à teoria da estratificação impulsionaram estudos que buscavam enfatizar o surgimento, sob a etapa monopolista do capitalismo, de uma nova classe média (Mills, 1969) (Lockwood, 1962). Em comum, procuraram afirmar que, a despeito da existência de aspectos comuns - proximidade dos níveis salariais, situação de mercado ou posição nas relações de trabalho semelhantes - tais fatores seriam insuficientes para garantir homogeneidade aos assalariados. Criticam o destaque dado à determinação econômica das classes sociais e chamam a atenção para a importância atribuída pela classe média ao prestígio social e ao 
status, fator que impediria sua junção ao operariado. Ou seja, o que diferenciaria a classe média - denominada "trabalhadores de paleto" (Lockwood) ou colarinhos-brancos (Mills) - do operariado seria o prestígio, sendo o sindicalismo de classe média explicado por tais autores com base da perda de prestígio desses assalariados.

No interior do campo marxista, a validade da "tese da proletarização" também é contestada por inúmeros autores, que consideram a fusão entre assalariados manuais e não manuais problemática (Wright, 1979) (Poulantzas, 1975) (Saes,1985).

Wright (1979) desenvolve a idéia da existência - entre os proprietários e os não-proprietários dos meios de produção, ou seja, entre capitalistas e operariado - de assalariados que estariam posicionados em "situações contraditórias de classes", ou seja, a noção segundo a qual, na divisão social do trabalho, haveria posições que seriam objetivamente contraditórias. Em sua análise, utiliza como base, tendências próprias às sociedades capitalistas avançadas, que seriam: a perda de controle sobre o processo de trabalho pelos trabalhadores, a diferenciação das funções do capital e o desenvolvimento de hierarquias complexas. Teriam desenvolvido-se complexas hierarquias de autoridade (nas empresas e burocracias capitalistas), fazendo com que se desenvolvessem, entre a burguesia e a classe operária, ao nível da formação social, além da pequena burguesia, ocupações que se situariam contraditoriamente em relação a essas três classes.

Poulantzas (1975) destacou, no seu estudo sobre as classes sociais, a existência de barreiras ideológicas separando o operariado da classe média, para a qual Poulantzas cunhou a expressão "nova pequena burguesia" Tal qual a pequena burguesia tradicional, os trabalhadores de classe média estariam marcados por alguns traços ideológicos como o individualismo e o fetiche do Estado.

Saes (1977), por sua vez, distingue a classe média não só do operariado, como também da pequena burguesia. Essa última seria composta por pequenos proprietários apegados à propriedade privada. Já a classe 
média, composta por assalariados não-proprietários, teria como traço ideológico fundamental, não o apego à propriedade privada dos meios de produção, mas a defesa da superioridade econômica e social do trabalho não-manual frente ao trabalho manual.

Saes (1985) designa por "classe média" os assalariados improdutivos não-manuais e considera que há um elemento ideológico que fixa os limites dentro dos quais se dariam as orientações políticas dos grupos médios, que se traduz por uma recusa ao nivelamento social entre trabalhadores manuais e trabalhadores não-manuais. $\mathrm{O}$ que eqüivale a afirmar que a "consciência média" é marcada pela recusa à igualização socio-econômica entre os "manuais" e os "não-manuais", em função da valorização dos "dons" e "méritos" dos quais estes últimos se julgam portadores. Em outros termos, os não-manuais possuem um apego à ideologia meritocrática. Afirma ainda não haver unidade ideológica e política da "classe média", ou seja, no conjunto dos trabalhadores não-manuais o que há são inúmeras variações, dadas segundo as diferentes situações de trabalho.

Nossas hipóteses, apresentadas neste artigo, servem-se da conceituação de classe média desenvolvida por Saes (1977) (1985).

\section{Classe Média e Sindicalismo}

Segundo nossa hipótese, dentre os assalariados médios é possível distinguir duas atitudes em relação ao sindicalismo. Há setores da classe média que se mantêm hostis à organização e à luta sindical; outros setores aderem ao sindicalismo, mas o praticam de um modo particular. Ao longo dos últimos anos, inúmeros setores de classe média superaram a atitude anti-sindical e passaram a integrar, à sua maneira, o sindicalismo. A situação de trabalho de cada setor da classe média, o apego maior ou menor de cada setor ao individualismo meritocrático e a conjuntura política são os fatores que explicam, segundo as hipóteses das quais partimos, a rejeição ou a adesão dos diferentes setores de classe média ao movimento sindical. 


\subsection{A ATITUDE ANTI-SINDICAL}

O apego à ideologia meritocrática é um primeiro fator que pode afastar os trabalhadores de classe média da organização e da luta sindical.

Composta por trabalhadores que exercem um trabalho socialmente definido como não-manual, a classe média tende a estigmatizar o trabalho manual, visto como atividade degradante. (Saes, 1977). Acoplada a essa divisão básica, a ideologia meritocrática tende a estabelecer, ainda, no seio do trabalho socialmente definido como não-manual, uma hierarquia de profissões e ocupações, merecedoras, cada uma delas, de distinção social e de um nível de remuneração adequados. $\mathrm{O}$ mundo do trabalho é concebido de modo segmentado e hierarquizado. A distribuição dos trabalhadores nessa hierarquia, que comporta desigualdades nas condições de trabalho, no nível de remuneração e no prestígio social, é apresentada, pela ideologia meritocrática, como resultado das desigualdades de dons e de méritos individuais existentes entre eles.

O trabalhador de classe média, em grau maior ou menor dependendo do setor e da conjuntura considerados, é apegado ao individualismo meritocrático. Ele tende a ver suas condições de trabalho e nível de remuneração como resultado dos seus dons e méritos pessoais. Essa visão pode gerar uma atitude anti-sindical. O sindicalismo passa a ser encarado como instrumento próprio dos trabalhadores manuais, que teriam que compensar através do engajamento político a sua falta de méritos (Boito Jr., 1992). As formas coletivas de luta aparecem, aos olhos de determinados setores assalariados médios, como formas degradantes de obter elevação salarial (Grun, 1990). A atitude anti-sindical traduz-se pela rejeição, por parte de inúmeros grupos de assalariados de classe média, à organização e à prática sindical. Mantêm-se refratários às formas coletivas de organização com finalidade de lutar por melhoria das condições de trabalho e de salários, embora possam ter experimentado o engajamento político ou a participação em lutas sociais de outra natureza que não a sindical, ingressando individual ou coletivamente em organiza- 
ções partidárias, instituições profissionais sem caráter sindical, organizações não governamentais (Ong’s), ou simplesmente participando de movimentos de defesa ambiental, em defesa dos direitos do consumidor; movimentos contra a violência urbana etc.

Outro fator que pode afastar setores de classe média da organização e da luta sindical são as características da situação de trabalho.

As relações que os trabalhadores de classe média estabelecem entre si e, eventualmente, com trabalhadores manuais nos locais de trabalho, variam muito de acordo com o setor de classe média que tomarmos em consideração. As formas de remuneração (salário, comissão, tarefa, participação nos resultados etc.), o nível de remuneração e a natureza da atividade são outros aspectos que diferenciam muito as situações de trabalho dos diferentes setores da classe média. Essas diferentes situações de trabalho podem articular-se, de modos distintos, com a ideologia meritocrática, e contribuir para reforçar uma atitude anti-sindical.

Com o intuito de analisar as razões para a resistência de assalariados médios ao sindicalismo, vale destacar a criação de instituições profissionais como as de gerentes e executivos, que se originaram em oposição às entidades sindicais, em que a valorização à profissão assume caráter central e tudo o que se refira à questão salarial é evitado (Grun, 1990). A razão para a não aceitação do sindicalismo parece estar associada ao fato de exercerem, em seus respectivos postos de trabalho, funções de comando sobre os demais trabalhadores, o que aparece como contradição com as ações coletivas organizadas contra os patrões. Por exercerem, por assim dizer, funções delegadas do capital, estariam entre os assalariados que ocupam situação contraditória de classe, em torno da burguesia, o que limitaria sua ação independente dos interesses dessa classe no campo político (Wrigth, 1979).

Outra forma de rejeição dos assalariados médios ao sindicalismo pode ser verificada a partir do exame de entidades sindicais com existência puramente formal, ou seja, que reúnem pouquíssimos adeptos e ja- 
mais procuraram empreender greves junto à base que deveriam representar. Entre essas entidades, podem ser citados o Sindicato dos Comerciários, Sindicato dos Advogados, entre inúmeros outros. O Sindicato dos Comerciários possui um quadro de filiados composto predominantemente por comerciários que trabalham em pequenos estabelecimentos. Ali, a situação de trabalho encontra-se geralmente marcada pela presença do dono do estabelecimento e pelo salário por comissão (segundo as vendas realizadas), condições que predispõem o comerciário muito mais ao comportamento individualista e marcado pela competição entre os colegas, do que às ações coletivas por melhores salários (Trópia, 1994).

Por último, é importante mencionar que a atitude anti-sindical pode permear até mesmo assalariados de setores que aderiram ao sindicalismo. Ou seja, mesmo dentre assalariados médios que organizaram entidades sindicais e/ou utilizaram métodos coletivos - como as greves - de pressão por salários, pode haver a persistência de rejeição, conforme parece ser o caso de professores universitários que se pronunciam publicamente contra o sindicalismo na universidade, criticando duramente os colegas por reivindicarem melhorias salariais paralisando atividades (Fantinatti, 1998).

\subsection{A ADESÃO AO MOVIMENTO SINDICAL}

Embora o apego ao individualismo meritocrático e diversas situações de trabalho apresentem-se como obstáculos à organização coletiva, assalariados de classe média podem - dependendo da conjuntura econômica de arrocho salarial e da situação específica de trabalho - aderir ao sindicalismo. Nesse caso, desloca-se a ênfase nos méritos individuais, prolongando-a na forma de ênfase nos méritos da profissão, dando origem a uma forma específica de sindicalismo: o sindicalismo meritocrático, segmentado pela profissão e marcado fortemente pelo corporativismo profissional (Boito Jr., 1992). 
O sindicalismo docente nas universidades ilustra o corporativismo profissional, tendo seu surgimento associado à formação da profissão acadêmica (Schwartzman, 1994). Boletins de associações sindicais dos docentes universitários do estado de São Paulo, cuja primeira greve foi realizada em 1979, em conjunto com demais setores do funcionalismo público estadual, refletem um anseio em receber, do governo do Estado, tratamento diferenciado no que se referia a negociações e a índices de reajustes salariais, sendo esta expectativa uma das componentes da reivindicação de autonomia universitária conquistada em 1988. Depoimentos de alguns docentes refletem uma preocupação não apenas em manter-se numa entidade que represente exclusivamente os docentes, como também o descontentamento frente a campanhas salariais realizadas em conjunto com os funcionários das Universidades. Alegam que os anseios de docentes e de funcionários não seriam os mesmos, não devendo ser considerada a hipótese de fusão das respectivas pautas de reivindicações (Fantinatti, 1998).

Os engenheiros, mesmo empreendendo lutas de caráter mais amplo que as questões diretamente ligadas ao universo da profissão, mostram-se movidos pela valorização da profissão: ao defenderem o desenvolvimento econômico independente, sentem-se parte dele, como profissionais (Larangeira, 1991). Por identificarem-se como fazendo parte do desenvolvimento nacional, suas atitudes no campo sindical podem refletir-se na forma de um sindicalismo particularmente ativo no que se refere à defesa da soberania nacional, em favor do desenvolvimento independente, da preservação do desenvolvimento científico e tecnológico no âmbito nacional, entendido como patrimônio público da Nação. Essa concepção impulsiona-os na direção de agregarem-se junto à frente de assalariados em lutas contra as privatizações, pela defesa de reservas de mercado como de informática, defesa dos setores energético, siderúrgico, nuclear, telefonia, como setores essenciais e que deveriam permanecer sob o controle nacional, na forma de monopólio estatal. 
No Brasil, a crise do período pós-milagre econômico atingiu todos os assalariados, tendo, sobre os assalariados médios, um impacto muito particular, à medida que frustra expectativas no que se refere à garantia de boas posições no mercado de trabalho, bem como bons salários que, na fase anterior, compensaram principalmente os portadores de diplomas universitários (Bonelli, 1990) - ao anunciar-se uma fase de desaceleração na oferta de empregos de nível médio, e de deterioração crescente dos salários pela inflação (Quadros, 1991). Essa degradação salarial parece ter constituído um dos fatores determinantes para que vários grupos de assalariados médios percebessem a condição de assalariamento e aderissem ao sindicalismo. Os funcionários públicos - nas esferas municipais, estaduais e federal - estariam entre os que mais sofreram perdas salariais no período.

Entre os autores que consideram o sindicalismo de classe média como um fenômeno diferenciado em relação ao sindicalismo dos assalariados manuais, destacamos também os trabalhos de Bonelli (1996) e os de Simões (1992).

Bonelli (1996) aponta o período de 1985 a 1986 como o de intensificação das greves de setores de classe média, ressaltando que as explicações sociológicas sobre o fenômeno enfatizaram preocupações em torno da perda de prestígio profissional, da queda no padrão de vida e do assalariamento das profissões de nível superior ${ }^{2}$. Também destaca

${ }^{2}$ Os anos 60 foram marcados por grande expansão do sistema universitário, que impulsionou o crescimento das profissões de nível superior no país. Parcelas crescentes de profissionais de nível superior passam a entrar no mercado de trabalho na condição de não-liberais, caracterizando um processo de ajuste às transformações na estrutura econômica brasileira colocadas pelo aprofundamento da etapa urbano-industrial. O processo de assalariamento, ao implicar a perda da condição liberal, impõe inúmeras dificuldades no que se refere à preservação de prerrogativas profissionais típicas da condição anterior, altera em profundidade as condições do exercício das respectivas atividades. Diversos estudos sobre as profissões de classe média procuraram dimensionar as modificações nas condições do exercício profissional de atividades que tiveram uma brusca queda no número de profissionais liberais, passando ao assalariamento. Em comum, revelam conseqüências como a perda de autonomia e controle sobre o trabalho, a burocratização crescente das atividades, a deterioração nas condições de trabalho, bem como a fragmenta- 
que as greves foram realizadas, principalmente por funcionários públicos, sobretudo nos setores de saúde e educação, englobando médicos e professores.

Simões (1992) observa a presença dos profissionais de nível universitário assalariados no movimento sindical, no final da década de 70, e tenta demonstrar o surgimento de novas "bases sociais" do sindicalismo no país, que contaria, a partir de então, com novo tipo de sindicalista: o profissional como o médico, o engenheiro etc. No estudo que empreende acerca do sindicalismo dos engenheiros, destaca que existiriam simultaneamente semelhanças e oposições em relação ao sindicalismo operário, não permitindo afirmar que a degradação de suas condições de trabalho e /ou dos níveis salariais representaria sua proletarização.

Afirmar que, devido a uma conjuntura particular, em que os salários e as condições de trabalho estejam deteriorados de modo significativo, assalariados médios poderão aderir ao sindicalismo, não equivale a admitir que, por essa razão, tendam a fundir-se ao proletariado. Segundo a hipótese da qual partimos, os sindicatos de assalariados não-manuais mantêm-se diferenciados - preservando características próprias (como uma atuação marcada pelo corporativismo profissional e a diluição da figura do empregador) - em relação aos dos trabalhadores manuais, embora com estes possam realizar alianças.

A) O corporativismo profissional: sindicatos organizados por assalariados não-manuais são segmentados pela profissão, sendo o corporativismo profissional uma de suas marcas mais características. Próprio dos grupos médios, o corporativismo profissional segmenta-se pela profissão, caracteriza-se por uma identificação coletiva que se restringe ao terreno sindical e ao âmbito particular da profissão. Apresenta como particularidade a defesa das desigualdades salariais em função de suposta hierarquia de méritos das profissões (Boito Jr., 1992).

ção inter-profissional, ou seja, a multiplicação de situações de trabalho no interior de uma mesma profissão (Durand, 1974) (Donnangelo, 1975) (Falcão, 1984) (Marinho, 1985). 
A defesa da hierarquia salarial aparece como um dos aspectos importantes do corporativismo profissional. Em função da crença numa hierarquia natural de dons e méritos, reivindicam salários diferenciados, segundo o mérito de cada profissão. Essa preocupação evidencia uma característica própria da classe média: a recusa à igualização sócioeconômica entre trabalhadores não-manuais e manuais (Saes, 1985). No discurso dos sindicatos de classe média é comum verificar-se a alusão a baixos salários em correlação com os patamares salariais de outras profissões ou ocupações, que deveriam -supostamente - estar abaixo. Trabalho sobre o sindicalismo bancário da década de 30 evidencia essa característica, ao mostrar que os bancários sentiam-se desvalorizados por terem salários equivalentes - ou apenas ligeiramente superiores - aos de copeiras, empregadas domésticas e motoristas particulares que prestavam serviços para os donos de bancos (Girardi Jr., 1995).

B) A diluicão da figura do empregador. os trabalhadores assalariados médios não se julgam em oposição direta aos capitalistas e empregadores, não os enxergam como oponentes. Isso faz com que os embates entre sindicatos de classe média e seus respectivos empregadores sejam de baixa intensidade.

No sistema universitário, o exercício de funções que implicam grandes responsabilidades na administração de uma Universidade pode colaborar para a diluição da figura do empregador - criando no docente a ilusão de que, por colaborar com a administração, não pertenceria ao coletivo de empregados. Pode-se também afirmar que o eventual crescimento do poder decisório de colegas de profissão nos cargos administrativos vem sobredeterminar essa diluição (Fantinatti, 1998).

Sobre a dificuldade de identificação coletiva, Trópia (1994) observou, ao analisar o comportamento sindical dos comerciários, que certas características da situação de trabalho - como a presença de rivalidades e competição - podem induzir tais assalariados de classe média ao isolamento, ao apego ao individualismo; que, em função da relação entre os 
vendedores e clientes, ocorreria um deslocamento, segundo o qual, o patrão é visto pelo comerciário como aliado, o cliente, como patrão e o colega como rival. Isso ilustra um aspecto da dificuldade das classes médias em definir o oponente social, e deve ser levado em conta mesmo quando se trata de um grupo médio que aceita os sindicatos e a greve como instrumento de luta.

\subsection{A HETEROGENEIDADE NO INTERIOR DAS PROFISSÕES MÉDIAS}

Ao pesquisarmos o sindicalismo de classe média, é preciso, segundo nossa hipótese, considerar a diversidade das situações de trabalho nas quais estão inseridos esses trabalhadores. Mesmo no universo das profissões, que, em geral, são vistas como segmentos homogêneos, as situações de trabalho variam, indicando a impropriedade dessa visão homogeneizadora.

A análise das profissões revela a existência de vasta heterogeneidade quanto às formas de trabalho (inserção como assalariado ou como profissional autônomo; diferentes graus de autonomia sobre o trabalho; exercício de função de comando ou de execução de tarefas; variação nos níveis e formas de remuneração; trabalho realizado individual ou coletivamente; existência ou não de mecanismos de controle rigoroso do cumprimento da jornada de trabalho etc.) A análise das diversificações internas das profissões de classe média nos interessa à medida que, por revelar diferenças significativas de situações de trabalho coexistindo numa mesma profissão, pode contribuir para as reflexões sobre as especificidades do sindicalismo de classe média, ou ainda sobre as razões para a não adesão de alguns setores médios ao sindicalismo.

$\mathrm{Na}$ bibliografia sobre as profissões, há inúmeros trabalhos que apontam para as fragmentações internas aos grupos profissionais. Relacionamos aqui algumas dessas abordagens.

Para Simões (1992), o equívoco de grande parte dos estudos - tanto marxistas, quanto weberianos - sobre os profissionais consiste justa- 
mente em que compreendem o grupo profissional como homogêneo. Tais estudos deixariam de mostrar as divisões de classe que perpassam os grupos, as quais constituem condição para compreender as diferentes formas de organização e a variedade de orientações políticas existentes. No trabalho que realiza sobre os engenheiros, mostra-os exercendo a profissão na condição de autônomos, empregadores, assalariados e também na forma por ela caracterizada como "posições contraditórias de classe", ou seja, como gerentes, supervisores e não-gerentes. Destacando a diferenciação no interior do grupo dos engenheiros, não os considera nem proletarizados, nem ao lado da burguesia. Haveria ao menos três situações: 1) engenheiros em vias de se proletarizar, 2) ocupando funções de mando e 3) situados em posições contraditórias entre a burguesia e o proletariado.

Kawamura (1979), que também realizou estudo sobre os engenheiros, observa que, ao ocuparem posições de mando, difundiriam a ideologia da burguesia. Aponta a fase monopolista do capitalismo como período a partir do qual as atividades que utilizam tecnologia complexa ganham relevo, sendo valorizadas as funções dirigentes dos engenheiros. Julga que seu trabalho contribui para a dominação burguesa, para a manutenção do modo de produção capitalista, classificando-os, assim, como intelectuais orgânicos da burguesia. A autora, entretanto, mostra que os engenheiros não formam um grupo homogêneo, havendo diferenciações entre os que exercem altos cargos, funções de mando, e os que executam tarefas mais próximas dos trabalhos manuais, ocupando postos de trabalho subalternos, em que exercem funções rotineiras. Essas diferenças repercutem de modo significativo no posicionamento dos engenheiros, impedindo afirmar que difundem uma mesma ideologia. Se os primeiros podem atuar como intelectuais orgânicos da burguesia, estes últimos ocupariam, segundo a autora, posições ambíguas como intelectuais, por aproximarem-se dos operários, em suas atividades. Assim, a definição da posição de classe dos engenheiros requereria a análise da posição que ocupam no sistema de produção. 
Entre os arquitetos, a diversificação das formas de trabalho no interior da profissão também pode ser verificada.

Segundo Durand (1972), a prática da Arquitetura teria organizadose a partir de pelo menos quatro formas diferenciadas e, conforme demonstra seu estudo sobre os arquitetos, a cada uma das formas estaria associada uma classificação simbólica, representando sucesso ou fracasso profissional, de acordo com a suposta liberdade de criação permitida em cada situação. Desse modo, o trabalho em ateliê de projetos simbolizaria sucesso profissional. Já o exercício profissional junto a grandes construtoras, indicaria a subordinação do arquiteto à lógica comercial. Quanto aos profissionais envolvidos com o planejamento urbano e outras atividades ligadas ao serviço público, seriam vistos como mal sucedidos e acomodados a trabalhos burocráticos. O mesmo estudo indica também as orientações opostas que existiriam entre os arquitetos: numa visão mais antiga, o arquiteto tido como artista e humanista, que pratica a arquitetura como sinônimo de arte e que preserva uma capacidade crítica em relação aos problemas, como os originados pela urbanização capitalista. $\mathrm{Na}$ visão mais atual, sobressaem as preocupações com a esfera técnica da arquitetura, sendo as preocupações do profissional voltadas para a garantia de reserva de mercado de projetos ou com melhoria do ensino na área.

A situação do exercício profissional para os médicos também pode ser caracterizada como heterogênea. Pesquisas realizadas junto aos médicos na grande São Paulo (Donnangelo, 1975), (Santos, 1995), revelaram que haveria médicos exercendo a profissão conforme modelo liberal (típico ou atípico), envolvidos com o empresariamento da atividade médica (donos de clínicas, por exemplo), assalariados, bem como médicos envolvidos em mais de uma dessas condições. As pesquisas mostram que a heterogeneidade de situações de trabalho existente no interior de uma profissão pode dar origem a diferentes orientações no campo político, contrariando a idéia segundo a qual um grupo profissio- 
nal age como grupo social coeso. As diferentes situações de mercado dos médicos fazem com que eles se posicionem de formas distintas em relação à profissão, à autonomia profissional ou à melhoria das condições de trabalho, sendo muito diversificados os respectivos anseios, tanto no que se refere a questões da ideologia profissional, quanto a visões sobre a sociedade. Explicam a heterogeneidade como conseqüência da ampliação do setor e do assalariamento e concluem que o processo levou à perda de autonomia sobre o trabalho. Com a introdução de novas técnicas nos serviços de saúde, crescem as especializações, dando origem também ao trabalho em grupo. A especialização trouxe, não somente a diversificação do trabalho entre os médicos, como também levou à dependência entre especialistas e a uma hierarquização entre os mesmos. A elevação dos custos da prática profissional - em função dos equipamentos caros - fez com que se generalizasse, de maneira crescente, o trabalho em grupo, numa dinâmica em que os hospitais ganham dimensão e a prática isolada da medicina vai tornando-se cada vez mais escassa.

Entre os advogados também se verifica a diferenciação de situações de trabalho. Houve grande expansão no número de profissionais dessa área no mercado de trabalho. Segundo aponta Falcão, o número de estudantes de Direito teria dobrado do final dos anos 60 ao final dos 70, tendo ampliado-se muito o número de advogados no país. Sua pesquisa, realizada nos anos 80, indicava uma multiplicidade de formas de emprego para os bacharéis em Direito, revelando entre elas advogados trabalhando em escritórios (individuais ou reunindo vários sócios), ou exercendo funções junto a departamentos jurídicos. Nesse último caso, podendo ser empregados de empresas privadas ou instituições públicas. Os dados do período apontavam que a maior parte era composta por assalariados, restando poucos na condição de profissional autônomo, o que implica no exercício da atividade de forma cada vez mais subordinada aos interesses dos respectivos empregadores, em detrimento de uma atuação mais livre e independente que caracterizaria o profissional liberal. Também fi- 
cou constatado que a maioria exercia outra atividade remunerada além da advocacia, atividade nem sempre jurídica (Falcão, 1984).

A heterogeneidade de situações de trabalho também pode ser verificada a partir dos trabalhos sobre a profissão acadêmica, embora a condição de assalariamento seja comum a todos. As condições de trabalho dos professores universitários variariam principalmente em função do tipo de instituição universitária em que trabalham.

Para os que trabalham em escolas isoladas e privadas de pouco relevo no campo acadêmico, predominam a pouca valorização do trabalho, sobrecarga de horas-aulas para compor o salário ou pouco vínculo com a atividade docente, exercida como "bico"; para os das instituições privadas e estaduais fora de São Paulo, contratos em tempo parcial, sem estabilidade, baixa especialização acadêmica e muitas horas-aula; para as públicas federais, qualificação média, tempo integral, estabilidade e produtividade científica relativamente pequena; para as universidades paulistas, professores mais qualificados, tempo integral, estabilidade e, além da docência, a dedicação a atividades de pesquisa (Schwartzman, 1992). Schwartzman (1992) julga que, à exceção das paulistas, nas demais instituições a profissionalização do professor universitário se deu de maneira imperfeita. Segundo o autor, o sindicalismo é bastante ativo nas federais. Nas paulistas, haveria pouca participação sindical. Nas explicações sobre tais suposições, está implícita a idéia segundo a qual a força do sindicalismo docente seria inversamente proporcional à qualidade da produção científica da instituição, sugerindo ser o sindicalismo uma arma dos pouco qualificados profissionalmente. Esse ponto de vista revela uma visão anti-sindical movida pelo apego ao individualismo meritocrático, que repele as lutas coletivas em favor da melhoria salarial e das condições de trabalho.

O estudo do movimento sindical nas universidades estaduais paulistas mostra a realização de inúmeras campanhas salariais, várias greves e mobilizações - sobretudo ao longo da década de 80 - o que contraria a 
versão segundo a qual teria pouco envolvimento com o sindicalismo. A análise concreta da situação de trabalho em tais universidades aponta que a diminuição das paralisações ao longo da década de 90 não está ligada à alta qualificação de seu corpo docente e de sua produção científica. Além de fatos conjunturais que afetam todo o sindicalismo na atualidade, o refluxo das greves pode ser explicado por uma alteração no sistema de gestão dos recursos da universidade, o qual, desde 1989, passou a ser regido pela autonomia universitária, em que o Reitor assume a figura do empregador nas negociações salariais e as reivindicações ficariam contidas pelos limites impostos pelo orçamento das universidades (Fantinatti, 1998).

\section{As Tendências Atuais do Sindicalismo de Classe Média NO BRASIL}

Muitas têm sido as modificações nas relações de trabalho no Brasil, sobretudo no período recente, com ênfase para medidas relativas à legislação trabalhista. Se a Constituição de 1988 representara significativo avanço no que se refere à consolidação dos direitos dos trabalhadores assalariados, a etapa que se seguiu operaria em direção oposta, em que a desregulamentação dos direitos do trabalhador entrou na ordem do dia.

Se a situação de trabalho de inúmeros assalariados vem passando por profundas modificações, vale referirmo-nos particularmente aos assalariados do funcionalismo público, responsáveis por grande presença no que se refere às atuações sindicais de classe média desencadeadas nos anos 80, e que apresentam-se, na atualidade, como alvos de políticas que alteram em profundidade sua situação de trabalho.

\section{O FunCIONALISMo PÚBLICo}

Os assalariados do setor público estão entre os que têm tido a situação de trabalho modificada pelas políticas neoliberais que vêm sendo 
implementadas pelo atual governo. "Bode expiatório para os problemas do Estado" 3 , o serviço público é alvo de medidas que ensejam a diminuição de suas proporções e o fim das garantias e direitos do trabalho (como estabilidade no emprego e aposentadoria integral). Vão nesse sentido a Lei de Reforma da Previdência Social e a Reforma Administrativa.

A regulamentação da reforma administrativa prevista pelo governo permitirá aos governadores demitirem servidores por excesso de quadros. Com ela, também torna-se possível a redução do quadro de funcionários públicos com a colocação de servidores em disponibilidade. Pela nova legislação, à qual os Estados devem enquadrar-se até o final de 1999, as despesas com pessoal ficam limitadas em, no máximo, 60\% da arrecadação, o que significa que poderá haver inúmeras demissões. ${ }^{4} \mathrm{~A}$ tendência à redução dos serviços públicos, bem como do funcionalismo, pode ser verificada também a partir da observação de que, em diversos setores, os concursos públicos para ingresso deixaram de ser realizados e as vagas deixadas por aposentados e/ou outros inativos não são preenchidas.

Os denominados setores sociais - educação e saúde - que estiveram na vanguarda do sindicalismo de classe média serão particularmente afetados. A educação tem o maior número de servidores públicos federais, vindo em segundo lugar os da saúde. De um total de 520.165 servidores civis ativos, 170.148 concentram-se na área de educação e 119.149 na de saúde. ${ }^{5}$ Consideradas as dimensões das respectivas áreas, não devem ser subestimados os eventuais impactos das modificações que vêm sendo feitas.

Vejamos mais de perto a situação desses setores.

${ }^{3}$ A expressão é de Ivan Valente.

${ }^{4}$ Folha de S. Paulo em 17/10/1998.

${ }^{5}$ Fonte: Ministério da Administração Federal e Reforma do Estado, Cf. Folha de S. Paulo em 11/10/1998. 


\section{OS DOCENTES UNIVERSITÁRIOS}

Como parte da política de redução de serviços públicos, muitas das universidades públicas - sobretudo as federais - vêm sendo alvo de sistemáticos cortes de verbas, o que as lança em condições precárias de desenvolvimento de atividades de ensino e pesquisa. A escassez de recursos afeta a manutenção de equipamentos, bem como as respectivas folhas de pagamentos. Em inúmeras universidades, a exemplo da Unicamp, estão suspensas novas contratações.

O movimento docente - tradicionalmente ativo - vem sofrendo derrotas sucessivas que se devem, em parte, às inúmeras possibilidades de arranjos individuais para superar a queda dos salários nas universidades públicas. Sobretudo nas instituições de prestígio e renome no que se refere à produção científica e tecnológica, os docentes complementam os salários através da prestação de serviços na forma de assessorias ou consultórios particulares, uma vez que o regime de trabalho que previa a dedicação exclusiva e integral à universidade vem sendo flexibilizado ou simplesmente burlado. Mesmo entre os que cumprem o regime, saídas individualizantes aparecem na forma de convênios com a iniciativa privada, mais comuns nas áreas tecnológicas, e que chegam a elevar em cerca de $100 \%$ os rendimentos. São os contratos de transferência de pesquisa denominados universidade-empresa. A padronização dos salários está cada vez mais reduzida. Ao longo da greve realizada de março a julho de 1998 pelas universidades federais, o governo e o MEC acenaram com aumentos salariais diferenciados, o que golpeou a isonomia salarial, tornando ainda mais diversificados os patamares salariais dos docentes. Todos esses aspectos dificultam a organização e a luta sindical dos professores universitários do setor público.

Lado a lado com a deterioração dos salários e das condições de trabalho no setor público, assiste-se à ampliação do setor privado, fortemente impulsionado pelas regras da nova LDB (Lei de Diretrizes e Bases da Educação Nacional). As regras para a constituição de novas 
universidades particulares estão menos rígidas e passa-se a admitir o lucro com o ensino. Para obtenção de autorização de funcionamento de instituições universitárias, de acordo com a nova LDB, não consta mais a obrigatoriedade de desenvolver pesquisa; foi consolidado o modelo de centros de excelência, os quais podem oferecer apenas ensino. O setor do ensino universitário que mais cresce - o setor privado - é justamente aquele no qual o movimento sindical docente é mais fraco.

\section{Os Professores de $1^{\circ}$ E $2^{\circ}$ GraUs}

A situação de deterioração salarial e das condições de trabalho para os professores de $1^{\circ}$ e $2^{\circ}$ graus - sobretudo no ensino público - não é nova, tendo sido problematizada em diversos estudos, os quais apontam causas situadas a partir da década de 60 (Pereira, 1969) (Pessanha, 1994). As modificações recentes pelas quais vem passando, e que alteram seu perfil, agravam ainda mais essa situação.

Cerca de dois terços dos professores da rede pública paulista de $1^{\circ}$ e $2^{\circ}$ graus trabalham, atualmente, com contrato precário ${ }^{6}$, situação inversa à verificada no período de expansão do sistema, em que a grande maioria era composta por concursados, com direito a estabilidade no emprego. Como conseqüência, na situação atual, um contingente maior tem estado sujeito a demissões - o governo do Estado de São Paulo demitiu cerca de 40 mil professores no último ano. Recentes alterações curriculares no sistema de ensino estadual fizeram com que inúmeras disciplinas - como História, Sociologia, Química, entre outras - tivessem o número de horas-aula semanais drasticamente reduzidas. Como resultado, muitos professores perderam a vaga ou tiveram uma atribuição de aulas reduzida.

Os professores em contrato precário não têm vaga garantida na escola em que lecionam (no ensino oficial, os concursados têm priorida-

\footnotetext{
${ }^{6}$ Fonte: Apeoesp (Associação de professores do Ensino Oficial do Estado de São Paulo).
} 
de no momento da atribuição das aulas) sendo grande a rotatividade de uma escola para outra a cada novo ano letivo. Isso traz dificuldades à formação de vínculos e identidades entre os professores, lançando novos desafios às entidades sindicais que os representam. Acrescente-se a isso o processo de municipalização das redes públicas estaduais que está fragmentando o movimento sindical dos professores.

\section{Os MÉDICOS}

Seguindo a referida tendência de diminuição dos serviços públicos, os hospitais públicos têm passado por sucessivas crises financeiras, tendo sido desativados inúmeros leitos, o que altera as condições de exercício profissional, obrigando os médicos a trabalharem em condições precárias de atendimento à população, gerando estresse no trabalho, segundo denunciam os sindicatos de médicos. A rede pública perdeu 6 mil leitos nos últimos seis anos, ou seja, o SUS (Sistema Unificado de Saúde), que possuía 496 mil leitos em 1992, passou a oferecer 490 mil em 1998. ${ }^{7}$

A deterioração dos salários dos médicos - tanto no setor público quanto no privado - obriga a uma jornada de aproximadamente 12 horas diárias, representando o triplo da jornada fixada segundo critérios da OMS (organização Mundial da Saúde) para tais trabalhadores, que é de 4 horas. O Salário inicial de um médico na rede pública estadual de SP é de R\$ 930,00 por 20 horas semanais e estima-se que $60 \%$ dos médicos brasileiros recebem em média $\mathrm{R} \$ 1.300$. Há 70 mil médicos trabalhando no Estado de São Paulo, onde existem 95 hospitais públicos e 563 privados. Apenas 5\% têm consultórios, sendo, o percentual restante, composto por assalariados. ${ }^{8}$

O crescimento do setor privado de saúde fez crescer o número de médicos assalariados nesse setor. A lógica empresarial que permeia as

\footnotetext{
${ }^{7}$ Fonte: Datasus, Cf. Folha de S. Paulo em 19/10/1998.

${ }^{8}$ Fonte: Sindicato dos Médicos do Estado de São Paulo e Seade (Fundação Sistema Estadual de Análise de Dados), Cf. Folha de S. Paulo em 8/10/1998. 
regras de funcionamento de tais estabelecimentos retira ainda mais a autonomia sobre o trabalho médico. Também como reflexo da expansão dos serviços privados de saúde, uma parcela dos médicos assume uma postura gerencial, um raciocínio empresarial, ao administrá-los.

Segundo Machado (1995), os interesses lucrativos dos hospitais limitam a autonomia do médico. O bem-estar do paciente choca-se com os interesses comerciais das instituições, fazendo com que tanto a autonomia quanto o ideal de trabalho médico fiquem abalados diante desses interesses. Santos (1995) também observa o processo de empresariamento do setor saúde - em que o "patrão" público passa a ter preocupações típicas dos empresários privados - definindo-o como contraditório com a prestação social de serviços. A formação profissional voltada à especialização precoce é exigida pelo mercado, o qual se volta para a prestação de serviços que envolvam maior aplicação de capital, com uso direto de tecnologia complexa, e que não visa atingir a população de baixa renda necessitada dos serviços de saúde. A especialização ou o "especialismo" atua como fator de fragmentação dos médicos, de elitização, fazendo com que já não possuam uma identificação recíproca. Essa seria uma das razões para o esvaziamento das entidades profissionais e tendência à diminuição da atividade sindical.

Alguns procedimentos adotados recentemente pelos hospitais e postos de saúde públicos - copiados do setor privado - modificam a situação de trabalho dos médicos. Alguns programas de atendimento (como o PAS, em São Paulo, entre outros), passaram a estipular o pagamento diferenciado ao médico, estipulado pelo procedimento, em substituição à remuneração por jornada de trabalho. Com isso, acelera-se a despadronização dos níveis salariais dos médicos no setor e as relações de trabalho entre os médicos podem tornar-se marcadas pela competição entre os que realizam procedimentos melhor remunerados e os demais, supervalorizando uma suposta hierarquia de especializações, os clínicos gerais constituindo a parcela inferior. 


\section{CONCluSÃo}

Em conclusão, diríamos que, segundo nossa hipótese, baseada neste levantamento preliminar das mudanças já esboçadas, novas dificuldades e entraves estariam colocados para a organização coletiva dos trabalhadores e com isso, novos desafios para os respectivos sindicatos que estiveram, até o presente, na vanguarda do sindicalismo de classe média. Deterioram-se as condições de trabalho e salariais, amplia-se o desemprego, e cresce também a fragmentação e individualização dos trabalhadores, complexificam-se as hierarquias e diversificam-se os níveis de remuneração no interior das ocupações, retirando elementos de padronização.

Paralelamente, os setores de serviços privados, nas áreas de saúde e educação, têm crescido. Os profissionais de classe média, quando empregados no setor privado, não têm demonstrado a mesma disposição e capacidade de atuação sindical que seus colegas do setor público.

Diante disso, colocam-se como indagações: Quais os impactos das mudanças na situação de trabalho das classes médias? Como estariam reagindo os assalariados de classe média? Qual o posicionamento de seus sindicatos? Justifica-se, pois, um dos intuitos do presente artigo, ou seja, o levantamento preliminar - ou provisório - de respostas a essas e outras indagações, a partir das quais, julgamos que poderão ser identificadas algumas das tendências atuais do sindicalismo de classe média.

Para o caso da década de 1990, que é o período que privilegiamos em nossa análise, o elemento principal a ser considerado é a política neoliberal. A aplicação dessa política tem alterado a situação de trabalho de inúmeros setores da classe média. Ao provocar modificações profundas no âmbito de trabalho, que atingem sobretudo o funcionalismo público, estaria impondo dificuldades ao sindicalismo dos setores de classe média mais ativos até então.

Do mesmo modo que a expansão dos direitos sociais fez crescer um setor de burocracia de Estado ligado, principalmente, à saúde e à 
educação, repercutindo positivamente na organização e na luta sindical da classe média, hoje podemos levantar a hipótese de que a política neoliberal, ao restringir os direitos sociais, debilita essa burocracia e, por conseqüência, talvez venha debilitar o próprio sindicalismo de classe média.

Entretanto, não julgamos demais sublinhar o caráter hipotético da presente colocação - bem como de outras apresentadas neste artigo - a qual está baseada apenas num levantamento preliminar de dados e cujo aprofundamento irá dar-se ao longo do desenvolvimento de nossa pesquisa de doutorado que, por ora, encontra-se em sua fase inicial.

ABSTRACT: This article intends to analyze particularities of the middle class trade unionism that differentiate it of the labor trade unionism. It presents, also, some elements for a comparative analysis among several sections that compose the middle class, to which we didn't consider as a homogeneous block: there would be sections that stuck to the unionism and the ones that didn't make it. The mentioned studies refer the: teachers, lawyers, engineers, architects, university teachers, doctors, commercial employee, managers, bank and public employees. Last, it indicates some recent transformations that come affecting the middle class and that can bring consequences for its respective unions.

KEYwORDS: Trade unionism; Social classes; Middle class.

\section{REFERÊNCIAS BIBLIOGRÁFICAS}

BOITO JR., A. Classe Média e Sindicalismo: uma Nota Teórica. In: JUNQUEIRA, L. A. P. (Org.) Brasil e a Nova Ordem Internacional (Anais do IX Congresso Nacional dos Sociólogos, S. Paulo, junbo/1992). São Paulo: Simesp, 1994, p. 207-213.

BONELLI, M. G. A classe média do "milagre" à recessão. São Paulo: Idesp, Monografias, no 4, 1990.

BONELLI, M. G., DONATONI, S. Os Estudos sobre Profissões nas Ciências Sociais Brasileiras. In: Revista Brasileira de Informação Bibliográfica em Ciências Sociais. Rio de Janeiro: Relume-Dumará / Anpocs, 1996, n. 41, p. 109-142. 
BRAVERMAN, H. Trabalho e Capital Monopolista. 3a ed., Rio de Janeiro: Zahar editores, 1981.

DONNANGELO, M. C. F. Medicina e Sociedade: o Médico e seu mercado de trabalho. São Paulo: Pioneira, 1975.

DURAND, J. C. G. O Arquiteto: Estudo Introdutório de uma ocupação. São Paulo, 1972. Dissertação (Mestrado) - Faculdade de Filosofia, Letras e Ciências Humanas, Universidade de São Paulo.

FALCÃO, J. A. Os Advogados: ensino jurídico e mercado de trabalho. Recife: Fundação Joaquim Nabuco/Editora Massanguana, 1984.

FANTINATTI, M. M. C. M. Sindicalismo de Classe Média e Meritocracia: o movimento docente na Universidade Pública. Campinas, 1998. Dissertação (Mestrado em Sociologia) - Instituto de Filosofia e Ciências Humanas, Universidade Estadual de Campinas.

GIRARDI JR., L. Classe Média, Meritocracia e situação de trabalho: O sindicalismo bancário de 1923 a 1944. Campinas, 1995. Dissertação (Mestrado em Ciência Política) - Instituto de Filosofia e Ciências Humanas, Universidade Estadual de Campinas.

GRÜN, R. A Revolução dos gerentes brasileiros, Campinas, 1990. Tese (Doutorado em Ciências Sociais) - Instituto de Filosofia e Ciências Humanas, Universidade Estadual de Campinas

KAWAMURA, L. K. Engenheiro: Trabalho e Ideologia. São Paulo: Ática, 1979.

LARANGEIRA, S. M. G. Classes Médias e Movimento Sindical: o caso dos profissionais de nível superior no Rio Grande do Sul. In: Revista São Paulo em Perspectiva. São Paulo, vol. 5, no 1, jan-mar, 1991.

LOCKWOOD, D. El Trabajador de la Clase Media, Um Estudio Sobre la Conciencia de Clase. Madri: Aguilar, 1962.

MACHADO, M. H. Sociologia das Profissões; uma contribuição ao debate teórico. In: MACHADO, M. H. (org.), Profissões da Saúde: uma abordagem sociológica. Rio de Janeiro: Ed. Fiocruz, 1995.

MARINHO, M. J. M. C. Profissionalização e Credenciamento: a politica das profissões. Rio de Janeiro, 1985, Dissertação (Mestrado), Iuperj.

MILLS, C. W. A Nova Classe Média (White Collar). Rio de Janeiro: Zahar Editores, 1969.

PEREIRA, L. O Magistério Primário numa Sociedade de Classes. São Paulo: Pioneira, 1969. 
PESSANHA, E. C. Ascensão e queda do professor. São Paulo: Cortez Editora, 1994

POULANTZAS, N. As Classes Sociais no Capitalismo de Hoje. Rio de Janeiro: Zahar Editores, 1975.

QUADROS, W. J. O "milagre brasileiro" e a expansão da nova classe média. Campinas, 1991. Tese (Doutorado) - Instituto de Economia, Universidade Estadual de Campinas.

RUMIANTSEV, A., GRUPPI, L., BARJONET, A. La Estructuta de la Clase Obrera de los Países Capitalistas. Praga: Editorial Paz y Socialismo, 1963.

SAES, D. Classe Média e Políticas de Classe - Uma Nota Teórica. In: Contraponto. Rio de Janeiro: Centro de Estudos Noel Nutels, $n^{\circ} 2$, novembro de 1977, pp. 96-102.

- Classe Média e Sistema Político no Brasil. São Paulo: T. A. Queiroz, 1985.

SANTOS, P. M. Profissão Médica no Brasil. In: op. cit.. Rio de Janeiro: Ed. Fiocruz, 1995.

SCHWARTZMAN, S. O futuro da educação superior no Brasil. In: PAIVA, V. (Org.) Dilemas do ensino superior na América Latina. São Paulo: Papirus ed., 1994.

SCHWARTZMAN, S., BALBACHEVSKY, E. A Profissão Acadêmica no Brasil. São Paulo: NUPES/USP, mimeo, maio/1992.

SIMÕES, S. Classe Média Profissional no Brasil: Teoria e Organização Política e Sindical. In: Ciências Sociais Hoje. Rio de Janeiro: Anpocs, 1992.

TRÓPIA, P. V. Classe média, situação de trabalho e comportamento sindical: o caso dos comerciários de São Paulo. Campinas, 1994. Dissertação (Mestrado em Ciência Política) - Instituto de Filosofia e Ciências Humanas, Universidade Estadual de Campinas.

WRIGHT, E. O. Classe, Crise e Estado. Rio de Janeiro: Zahar, 1979. 